\title{
宾戸先生を偲んで
}

\section{木下 宗七}

(名古屋大学名誉教授)

PAPAIOS の 2 代目の会長であり尾崎先生, 筑井先生の 3 先生とともに学会の発展に貢献さ れた筑波大学名誉教授の宍戸駿太郎先生が, 昨 年 11 月 28 日, 病気のため逝去された。享年 92 歳である。

宍戸先生は, 経済企画庁総合計画局で計量分 析を担当され, 経済企画庁審議官を経て, 筑波 大学の副学長, 社会工学系教授として転出さ れ, さらに国際大学学長を務められた。国際大 学在籍時の 1999 年には The Journal of Econometric Study of Northeast Asia という英文ジ ヤーナルを Economic Research Institute for Northeast Asia（公益財団法人環日本海経済研 究所) から創刊 (同雑誌は 2015 年より Asian Growth Research Institute（公益財団法人アジ ア成長研究所）に移籍）され，東アジア経済の 計量モデル分析を推進された。私も今年まで編
集委員を務めている。

宍戸先生はここ数年来「日本経済の成長力」, 「世界と日米経済」などをテーマにモデル分析 を続けてこられ，私も共同研究に加わることが できた. Demios (Dynamic Econometric Model with I-O System）は 90 年代に宍戸先生が構築 した多部門計量経済モデルである。

2013 年に亡くなられたノーベル賞経済学者 クライン先生の率いる WEFA マクロ計量経済 モデリングの記録を，市村真一先生を中心とし て編集・出版するため，ここ1〜2 年宍戸先生 とも連絡を取り合っていたところであった。昨 年入院されたとうかがってはいたが，まもなく 出版できそうという段階にきて, 宍戸先生が亡 くなられ誠に残念である。

先生のご冥福をお祈り申し上げる。 